\title{
The diary of Bertha Marks as a heterotopia, as articulated in the artwork, The Futility of Writing 24-Page Letters
}

Authors:

Leora Farber ${ }^{1}$

Elfriede Dreyer ${ }^{2}$

\section{Affiliations:}

${ }^{1}$ Research Centre: Visual Identities in Art and Design, University of Johannesburg, South Africa

${ }^{2}$ Department of Visual Arts, University of Pretoria,

South Africa

Correspondence to: Leora Farber

Email:

leoraf@uj.ac.za

Postal address:

86 5th Avenue, Melville,

Johannesburg 2092,

South Africa

Dates:

Received: 10 Aug. 2011 Accepted: 17 Jan. 2012

Published: 13 Nov. 2012

How to cite this article:

Farber, L. \& Dreyer, E., 2012

'The diary of Bertha Marks as a heterotopia, as articulated in the artwork, The Futility of Writing 24-Page Letters', Literator 33(1), Art. \#29,

11 pages. http://dx.doi.org/

10.4102/lit.v33i1.29

Note:

This article is an output of Leora Farber's DPhil in Fine

Arts in the Department of Visual Arts, University of Pretoria, conducted under the supervision of Prof. Jeanne van Eeden and Prof. Elfriede Dreyer. The contents of the article correlate with Chapter Four of her doctoral dissertation.

This article was written as part of, and functions within the scope of a larger research project entitled Transgressions and boundaries of the page: $A$ transdisciplinary exploration of a practice-based research project by means of the artist's book conducted by the subject groups Graphic Design, Creative Writing and Art History at the Potchefstroom Campus of the North-West University, South Africa.
This article explored the conception, historical context and theoretical underpinnings of Leora Farber's 2010 artwork entitled The Futility of Writing 24-Page Letters, which forms an extension of the work on her exhibition entitled Dis-Location/Re-Location. The Futility of Writing 24-Page Letters falls within Dis-Location/Re-Location's thematics, but focuses on one aspect thereof, namely, how fin-de-siècle Jewish colonial women who were immigrants to southern Africa, as exemplified in the persona of Bertha Marks (1862-1934), experienced nineteenthcentury Victorian gender ideologies. Their life experiences often entailed resistance to their positions as subjects of a patriarchal social system; yet, as women, they were simultaneously complicit in upholding discriminatory colonial ideologies and in maintaining the racial, social and cultural prejudices and forms of subjugation that underpinned them. Bertha Marks is shown to have occupied a personalised heterotopia: whilst operating from within, and maintaining the racial and social prejudices of the colonial era, she was simultaneously constrained by her positioning within it. This heterotopic life experience is reflected in the diary extracts which comprise The Futility of Writing 24-Page Letters, which reveal that she occupied the conflicting positions of victim, witness, bystander, collaborator and beneficiary of colonial injustices and exploitation, and assumes varying degrees of co-responsibility and co-liability for her roles and actions.

Die dagboek van Bertha Marks as 'n heterotopia, soos verwoord in die kunswerk, The Futility of Writing 24-Page Letters. Hierdie artikel ondersoek die konsepsie, historiese konteks en teoretiese raamwerk van Leora Farber se 2010 kunswerk The Futility of Writing 24-Page Letters wat ' $\mathrm{n}$ voortsetting is van haar uitstalling Dis-Location/Re-Location. The Futility of Writing 24 Page Letters val binne die tematiek van Dis-Location/Re-Location, maar beklemtoon één aspek van laasgenoemde, naamlik hoe fin-de-siècle Joodse koloniale immigrante vrouens in SuiderlikeAfrika - soos versinnebeeld in die persona van Bertha Marks (1862-1934) - negentiende-eeuse, Viktoriaanse genderideologieë ervaar het. Hierdie vrouens se lewenservarings het dikwels verset teenoor hul posisies as subjekte van 'n patriargale sosiale sisteem behels, tog, as vrouens, was hul tegelykertyd medepligtig aan die onderskraging van diskriminerende koloniale ideologieë, en aan die handhawing van die rasse, sosiale en kulturele vooroordele, asook vorms van onderdrukking, wat hierdie ideologieë ingelig het. Daar word geargumenteer dat Bertha Marks 'n verpersoonlikte heterotopia bewoon het; terwyl sy haar plek binne die struktuur van die rasse- en sosiale vooroordele van die koloniale tydperk ten volle ingeneem het, was sy terselfdertyd beperk deur haar posisionering binne dié raamwerk. Hierdie heterotopiese lewenservaring word weerspieël in die dagboekuittreksels waaruit The Futility of Writing 24-Page Letters bestaan. Daarin word haar teenstrydige posisies as slagoffer, getuie, bystander, meeloper en begunstigde van koloniale onreg en uitbuiting geopenbaar, en aanvaar sy in wisselende mate mede-verantwoordelikheid en mede-aanspreeklikheid vir haar rol en optrede.

\section{Introduction}

The Futility of Writing 24-Page Letters ${ }^{1}$ (Farber 2010) is an artwork that forms an extension of the work on Leora Farber's (2007-2008) exhibition entitled Dis-Location/Re-Location. ${ }^{2}$ Futility falls within Dis-Location/Re-Location's thematics, which explore constructions of South African immigrant, first-generation and second-generation female Jewish identities, but focuses on one aspect thereof: how both the life experiences and consequent diary entries of fin-de-siècle immigrant 1. Hereafter referred to as Futility.

2.The Dis-Location/Re-Location exhibition travelled to seven national South African galleries and museums from June 2007 - September 2008.

Project web page: www.bookboek.co.za

Copyright: (c) 2012. The Authors. Licensee: AOSIS OpenJournals. This work is licensed under the Creative Commons Attribution License. 
colonial women to the Zuid-Afrikaansche Republiek (ZAR), in this case exemplified in the persona of Bertha Marks (1862-1934), could be considered as heterotopic.

Bertha Marks was an English, Orthodox Jewish woman and wife of the highly successful entrepreneur, Sammy Marks. ${ }^{4}$ After having arrived as an immigrant from Sheffield to southern Africa in 1885, at the age of 22, to enter into what is thought to be an arranged marriage, Bertha Marks lived an insular life in which hierarchical Victorian conventions of class, language, race and gender differences were upheld. These conventions were underpinned by the privileging of Whiteness as a product of race and social class. In this article, it is argued that Bertha Marks occupied a personalised heterotopia 5 : her life experiences in the ZAR were characterised by ambivalences between occupying the gendered position of being subject to patriarchal restrictions and subjugations, yet, paradoxically, also being complicit in maintaining her position of isolation and the inequalities of colonialism by virtue of her privileged Whiteness. The heterotopic nature of her life experiences is reflected in the diary extracts which comprise Futility, wherein she is shown to be accepting of, yet resistant to, the conventions and constraints of Victorian and colonial norms, and as collaborating with, and benefiting from, colonial injustices and exploitation. Furthermore, the suggestion is raised that the diary, insofar as it functions as a representation of her experiences, may be considered as a heterotopic site in itself.

It is commonly noted that many studies in African and imperial history neglect women and gender (Bailey 1983; Bradford 1996:370; Van Helten \& Williams 1983; Van Heyningen 1993). In these studies, representation of women and their experiences tend to be overlooked as 'unimportant', resulting in flawed analyses of both men and the colonial encounter. Where information is provided, it usually focuses on biographical and anecdotal detail (Van Helten \& Williams 1983). Given the paucity of information about women who immigrated to southern Africa as early settlers, women's writings in the form of letters and diaries are now being recognised as important, yet underutilised, historical sources (see Erlank 1995, 1996; Hugo 1989; Van Heyningen 1993). ${ }^{6}$

3.Informally known as the 'Transvaal Republic', the Zuid-Afrikansche Republiek (ZAR) was an independent Boer-ruled state in southern Africa during the second half of the nineteenth century. It occupied the area later known as 'the Transvaal', from 1910 a Province of the Union and later (1961-1994) of the Republic of South Africa (South African History Online n.d.). The term 'southern Africa' refers to the southernmost region of the African continent, encompassing numerous territories.

4.Sammy Marks was born in Lithuania in 1844. At the age of 16, he left Russia for England, where he settled in Sheffield. Seven years later, he immigrated to South Africa. Arriving in South Africa in 1868, Marks bears later, he immigred to South Africa. A riving in South Africa in 1868, Marks began trading as a smous - a term used to describe the itinerant Jewish trader who peddled his wares amongst the rural Boers (Mendelsohn \& Shain 2008.54). He joined the diamond rush to Kimberley and, within a decade, made his first fortune through diamond dealing and investing in claims. He made his second fortune in the Transvaal, as the founde of the Highveld coal-mining industry, the creator of the South African steel industry, an investor in property, and as the proprietor of a notorious liquor distillery nea Pretoria. This was followed by the establishment of glass and jam factories, as well as brickworks (Mendelsohn 1991:23-115).

5.Following Michel Foucault's ([1967] 1986) definition of the term 'heterotopia' as described in his paper: Des espaces autres', wherein it is described as a site of displacement (Johnson [2006:77], emphasis added) or a 'space of otherness' located in an already existing place.

6. Helen Bradford (1996:352) comments that in many historical texts, women are not only neglected, but their existence is linguistically denied. Many historians subsume women under the category 'man', and the 'ordinary person' is usually subsume women under the category 'man', and the 'ordinary person' is usually
conceptualised as male. If referred to, women are labelled as a 'wife', 'widow', conceptualised as male. If referred to, women are labe
'sister-in-law', 'sister' or 'daughter' (Bradford 1996:356).

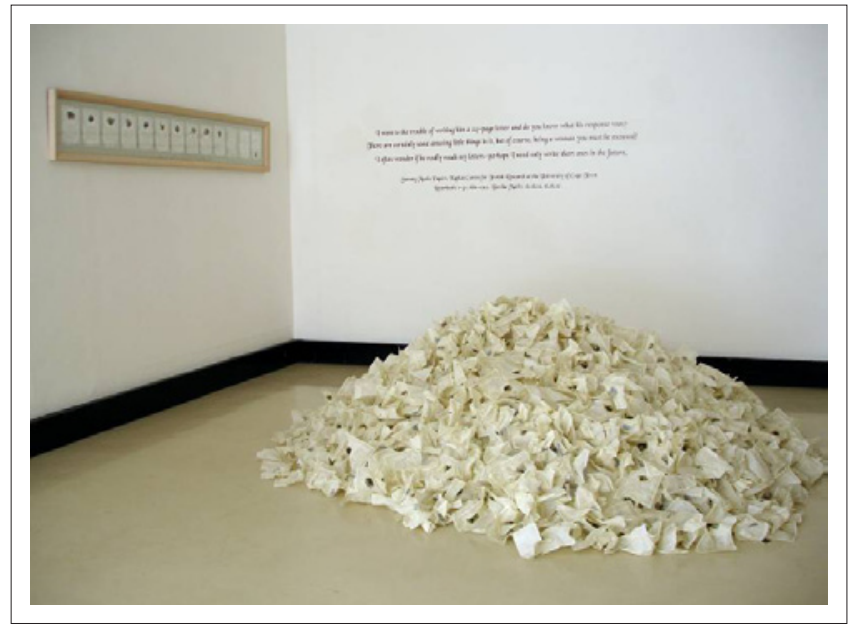

Source: Photograph by Charles Blackbeard. Permission to reproduce the image was obtained from the Noth-West University, Potchefstroom Campus, South Africa

FIGURE 1: A view of all three components within Leora Farber's artwork, The Futility of Writing 24-Page Letters, as exhibited at the University of Johannesburg's Faculty of Art, Design and Architecture (FADA) gallery, 12-23 July 2010.

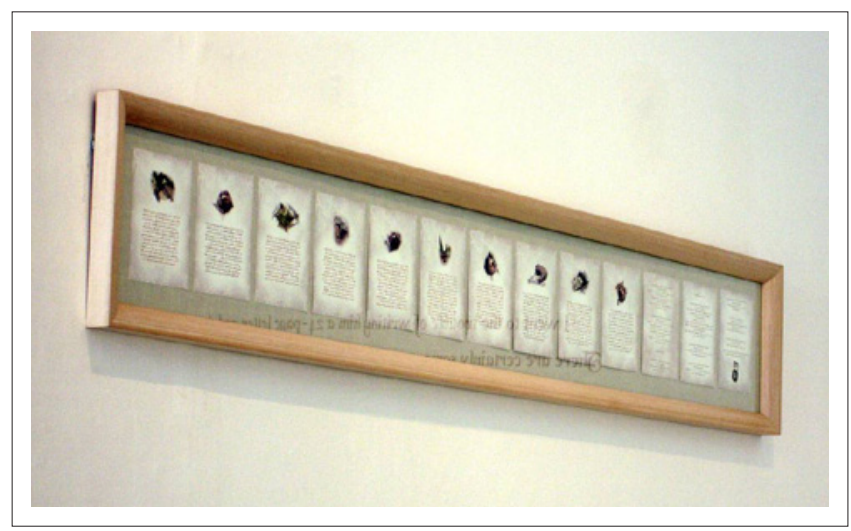

Source: Photograph by Charles Blackbeard. Permission to reproduce the image was obtained from the Noth-West University, Potchefstroom Campus, South Africa

FIGURE 2: The first component of Leora Farber's 2010 artwork, The Futility of Writing 24-Page Letters, is a framed series of 13 A5 sheets of paper representing the pages of a woman's diary and featuring paraphrased extracts or direct quotations from Bertha Marks's letters to her husband, Sammy Marks.

Susan Bailey (1983:11; see also Van Heyningen 1993:14) notes that journals, diaries and letters written by immigrant women in South Africa and other British colonies are all that remain to represent their experiences, perceptions and problems. Letter-writing carried tremendous import (Erlank 1996:82), given that, in most instances, it was the only means by which these women could maintain links with families, friends and children who had been sent abroad to boarding school. These women's letters reflect a wide range of topics, including both public and domestic concerns, although their families usually formed the main topic of discussion (Erlank 1996:78). Although the content of the letter might initially seem trivial, repetitive and/or meaningless, Elizabeth van Heyningen (1993:14) points to their immediacy and intimacy, and to ways in which they can reflect the writer's state of mind. Thus, immigrant women's letters should not be viewed as merely reflective of their physical situations; as Natasha Erlank (1996) observes with reference to the letters of middle-class women in Cape Town from 1825-1845:

the practice of letter-writing occurs in private - what has been referred to as a 'confessional' form of discourse. Its very personal nature allows it to be used to say things that cannot be expressed 


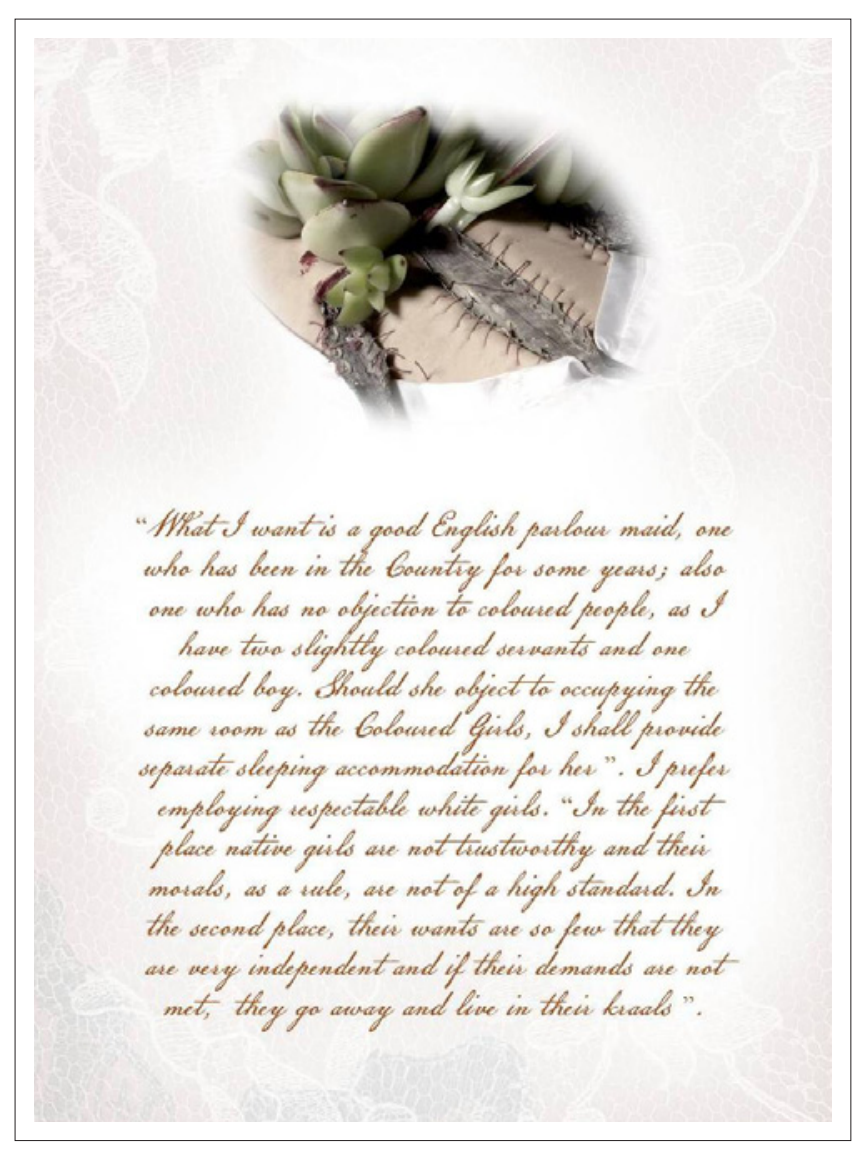

Source: Permission to reproduce the image was obtained from the artist, Leona Farber

FIGURE 3: Diary entry one, within the first component of Leora Farber's 2010 artwork, The Futility of Writing 24-Page Letters.

in more public forms of discourse. For this reason, letters are ideally suited for the asking of questions about the construction of personal identity, as well as the negotiation of broader, social and political issues on a personal level. From this perspective, letters are not only reflective of context, but also constitutive of context. (p. 85)

Van Heyningen $(1993: 21,22)$ extends this view by pointing out that letters and diaries also reflect ways in which Victorian class, race and cultural values were transmitted through women and provide knowledge of labour relations between Black and White people in the home. They also capture how class and gender discriminations were translated into racial attitudes (Stoler 1989:652) and reveal how notions of femininity and domesticity were not marginal to colonisation, but underscored the project of Empire-building (Rosner 1999).

As shown in Figure 1, Futility consists of three components. The first is a framed series of 13 A5 pages (Figure 2), pink in colour and delicately edged with printed lace, which, given Bertha Marks's Victorian context, may be construed as feminine. The first 10 pages are intended to resemble a woman's diary entries (Figures 3-5). Printed in a script-like font that simulates handwriting, these excerpts are either paraphrased extracts or direct quotations from Bertha Marks's letters to her husband. The references for these quotations are listed in the remaining three A5 pages. Upon reading these letters, her words, intimate and personal as they are, written in her hand, struck the artist as particularly poignant. In them, Marks not only gives voice to her frustrations as a

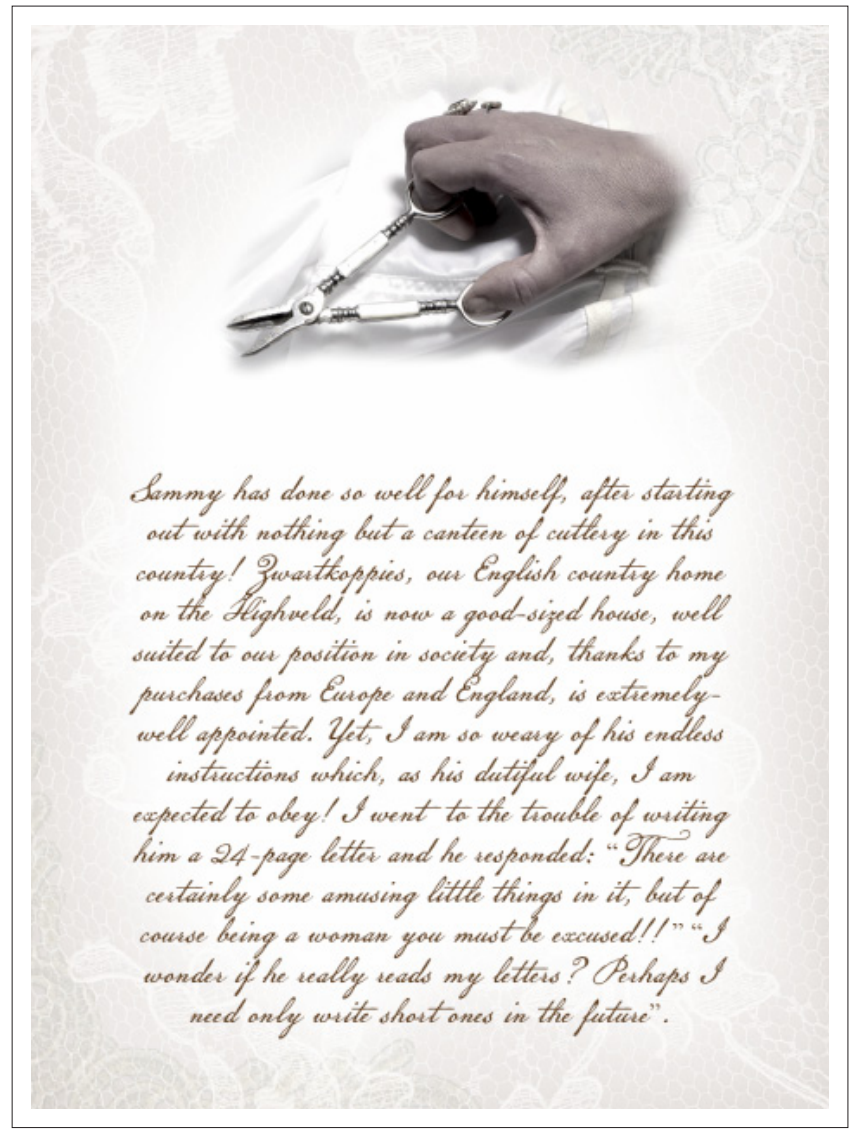

Source: Permission to reproduce the image was obtained from the artist, Leona Farber FIGURE 4: Diary entry eight, within the first component of Leora Farber's 2010 artwork, The Futility of Writing 24-Page Letters.

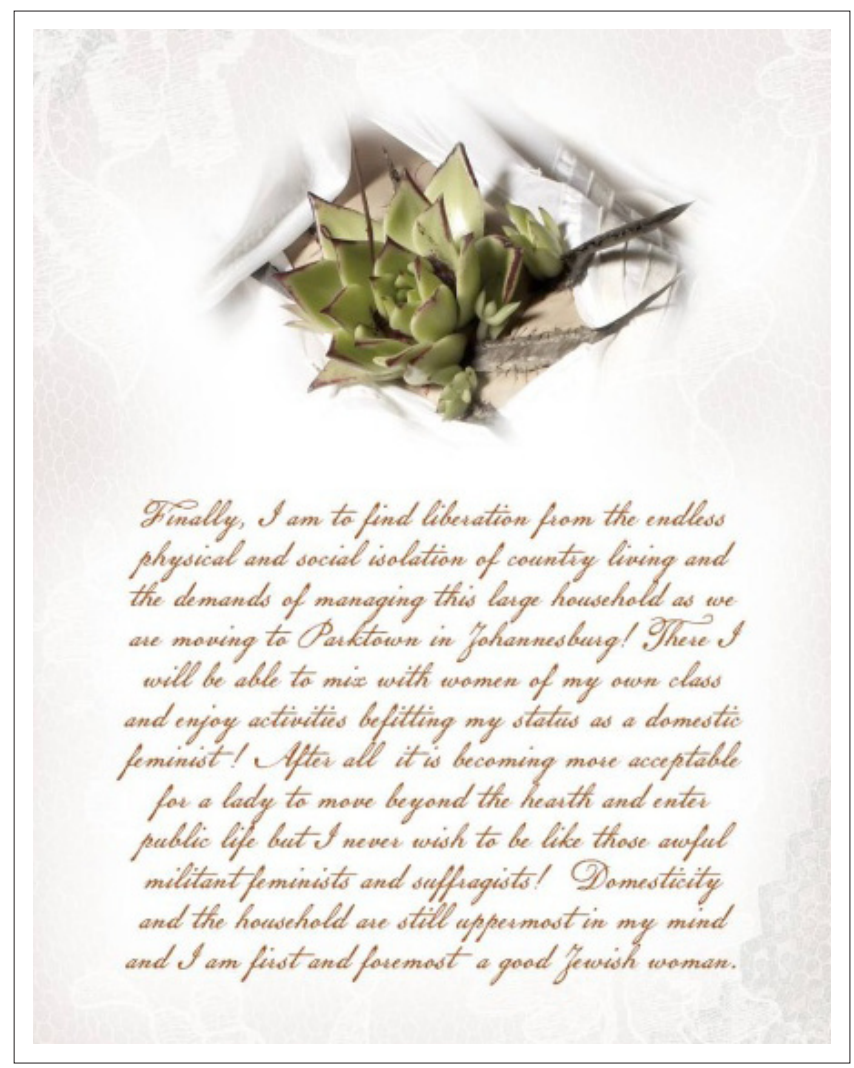

Source: Permission to reproduce the image was obtained from the artist, Leona Farber FIGURE 5: Diary entry three, within the first component of Leora Farber's 2010 artwork, The Futility of Writing 24-Page Letters. 
Victorian wife, woman and mother, but reveals much about her husband's patriarchal views, as well as her own colonial prejudices. At the top of each extract is a small printed image. These images include aloe leaves, which appear to have been stitched into a woman's flesh (Figures 3 and 5), a small Victorian sewing kit, a hand holding a pair of needlework scissors (Figure 4), and a wax rose cameo that has been inserted into a cut in a woman's breast, repeated from three different angles. In this work, as in others on Dis-Location/ Re-Location, the cameo is used as a metonym for a range of Anglo-Saxon values, attitudes, morals, behaviours and beliefs. In Bertha Marks's case, these received inheritances relate directly to her colonial 'Whiteness', which she may have felt that she needed to retain in order to preserve the integrity of her Anglo-Saxon identity. The choice to frame the diary extracts in an enclosing frame is intended to convey notions of utopian, colonial and Victorian 'closed' frames of mind.

The second component comprises a large pile of the above prints that have been discarded: crumpled, torn and thrown onto the floor (Figures 6 and 7). Care was taken to select a transparent, ivory-coloured paper which appears as if slightly yellowed through ageing. The transparency of the pages is intended to suggest skeins of Caucasian skin. A quotation taken from one of the diary extracts, printed in alizarin crimson vinyl lettering and mounted onto the wall adjacent to the framed set of prints, forms the third component (Figure 8).

Whilst Sammy Marks's rags-to-riches story as a successful entrepreneur is extensively documented, one of the factors which attracted the artist to the historical figure of Bertha Marks was the paucity of information available on her. This lack of information made her an intriguingly enigmatic figure for the artist. In the making of Futility, the two primary sources available were drawn on: the first being Richard Mendelsohn's (1991) biography of Sammy Marks, particularly his chapter, 'The gilded cage: Zwartkoppies after the war', in which he provides factual details of Bertha Marks's roles within a hierarchically ordered Victorian society. In addition, Mendelsohn (1991:181-195) details how Bertha Marks might have felt about having been moved from an upper-middle class Jewish family (Mendelsohn 2008:35) to come to South Africa; her sense of physical, social and psychological isolation at Zwartkoppies - the mansion Sammy Marks built for her and their eight children, her homesickness and longing for England, and the patriarchal power dynamics upon which their marriage was constructed. Mendelsohn conveys a clear sense of Bertha Marks's ambivalence towards these conditions: whilst accepting them, she also harboured and displayed a degree of resentment and resistance to the limitations of her position within the confines of Victorian constructions of femininity.

The second source is Bertha Marks's original letters to her husband, currently housed in the Samuel Marks Papers Archive, at the Isaac and Jessie Kaplan Centre for Jewish Studies and Research, University of Cape Town. These letters, which Bertha Marks sent to her husband whilst she

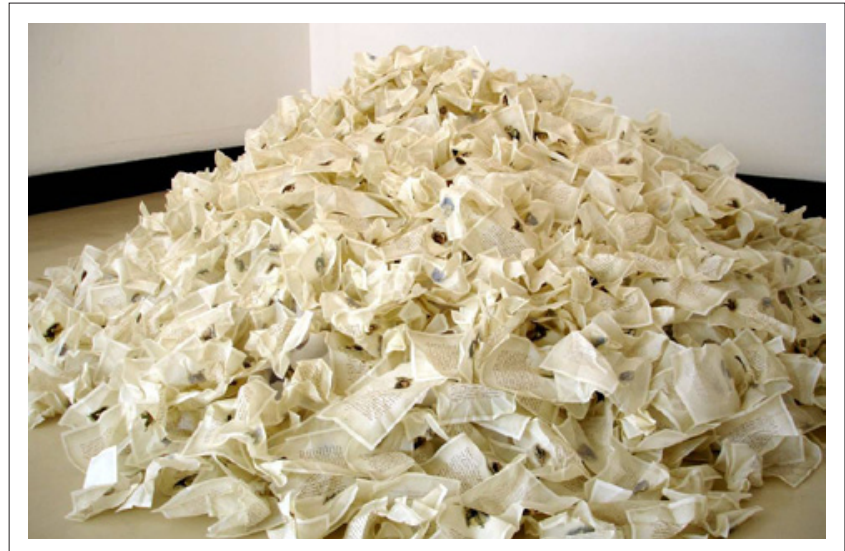

Source: Photograph by Charles Blackbeard. Permission to reproduce the image was obtained from the Noth-West University, Potchefstroom Campus, South Africa

FIGURE 6: The second component of Leora Farber's 2010 artwork, The Futility of Writing 24-Page Letters, representing crumpled and discarded diary pages and letters.

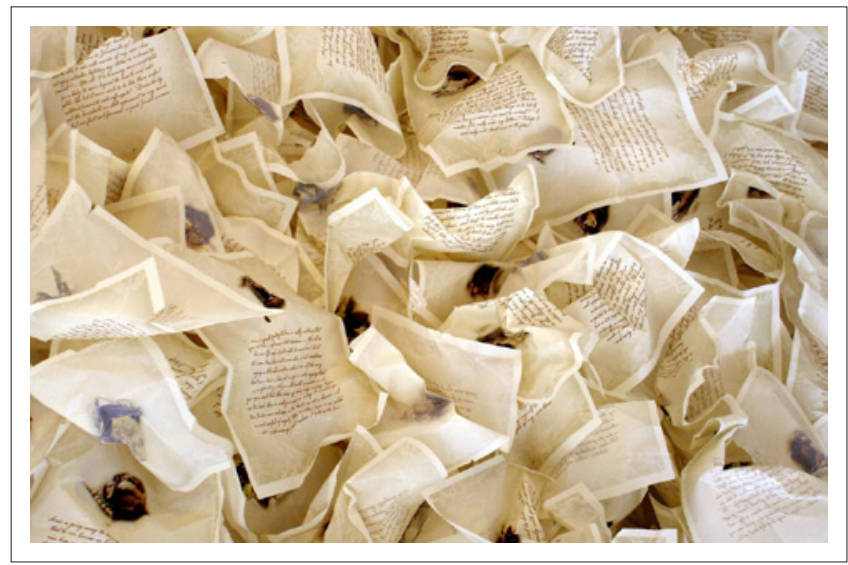

Source: Photograph by Charles Blackbeard. Permission to reproduce

the image was obtained from the Noth-West University, Potchefstroom Campus, South Africa

FIGURE 7: A detail of the second component of Leora Farber's 2010 artwork, The Futility of Writing 24-Page Letters.

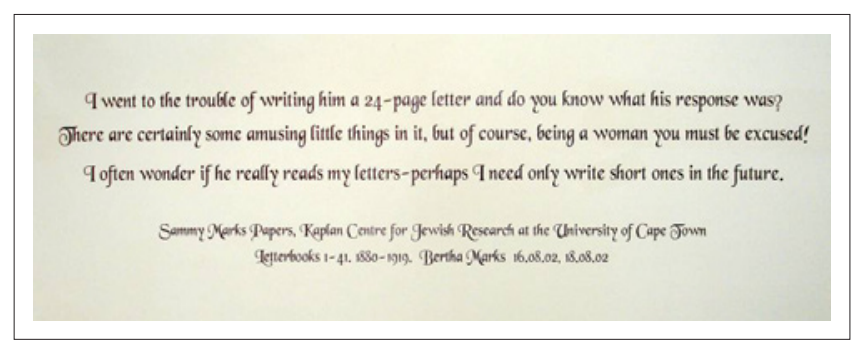

Source: Photograph by Charles Blackbeard. Permission to reproduce the image was obtained from the Noth-West University, Potchefstroom Campus, South Africa

FIGURE 8: The third component of Leora Farber's 2010 artwork, The Futility of Writing 24-Page Letters, featuring an extract from one of Sammy Marks's letters to his wife, Bertha Marks, from which the artist drew inspiration for the exhibit title.

was in England or from their holiday home in Cape Town, or to Sammy Marks from Zwartkoppies when he was away on business, are useful in that they provide further insight into her frustrations, loneliness, homesickness, alienation from her environment in South Africa, and concern for the Jewish upbringing of her children, as well as her ingrained colonial prejudices and values.

Although the empirical facts of her life experiences and quotes from her letters provided the basis for the artist's 
perceptions of her persona, some personal interpretation and imaginative projection was necessary to 'fill in' certain gaps in the primary sources. In extrapolating on the information gained from my primary sources, the artist was not attempting to 'speak for' Bertha Marks, but rather to evoke a sense of 'empathic unsettlement' - a term used by Dominick LaCapra (2001:87) in his work on trauma and representation - to denote an experience of otherness, by putting 'oneself in the other's position while recognising the difference of that position and hence not taking the other's place'.

\section{Heterotopias}

Before considering how Bertha Marks's life experiences in South Africa, and by extension, her diary entries as featured in Futility, are heterotopic, a brief outline of the term is provided. Whilst it was initially used to describe the process whereby a lump of flesh or organ is transplanted to another part of the body, the term 'heterotopia' can also be used to refer to parts of the body that are out of place, missing, extra, or alien. Derived from the Greek heteros [another] and topos [place], the term signifies the site of dislocation (Johnson 2006:77, emphasis added). The flesh or organ operates in a new environment, revealing the functions of its surrounds through difference. Michel Foucault ([1967] 1986) extends the medical term to apply to social space; the body becomes an occupied space in society, and the transposed flesh or organa site of cultural and social significance which inversely mirrors the values associated with that space. Removed from its original surroundings, a heterotopia reveals the nature and function of the space within which it is located, yet from which it is isolated (Jorgensen 2010:4). Heterotopias are therefore 'counter-hegemonic spaces that exist apart from "central" spaces that are seen to represent the social order' (Hetherington 1997:21).

Following the medical origins of the term, a heterotopia can be considered as a 'real' dislocated site which may occupy mental, imaginative and/or physical space, in contrast to utopias,? which are 'fundamentally unreal spaces' (Foucault [1967] 1986:4). Heterotopias can be material as well as conceptual, virtual and immaterial spaces, or urban and geopolitical spatial constructs (such as hinterlands, wonderlands and borderlands). Thus, like the bodily site onto which the flesh or organ has been transplanted, spatial heterotopias can potentially transform into:

places of Otherness, whose Otherness is established through a relationship of difference with other sites, such that their presence either provides an unsettling of spatial and social relations or an alternative representation of spatial and social relations. (Hetherington 1997:8)

Foucault ([1967] 1986:24-27) classifies heterotopias according to six principles. Firstly, although the forms they take are heterogeneous, heterotopias are universal. Secondly, heterotopias function in relation to all sites. The latter principle includes 'heterotopias of illusion' which create a

7.Utopia, a term coined by Sir Thomas More ([1516] 1985), expresses the desire for a better way of life; a space occupied by those wishing to 'make some change to society and seeking to bring about that change' (Hetherington 1997:123). It is usually used in the context of trying to create the perfect society - one that is is usually used in the context of trying to create the perfect society - one that is
ordered, stable and properly governed, in which the principles of freedom are upheld (Hetherington 1997:vii). space of illusion which exposes real space; and 'heterotopias of compensation' which create a real space that is other (Topinka 2010:56, 57). Thirdly, society can refashion their use over time to allow them to function in different ways. Fourthly, a heterotopia may be a single, real place in which several spaces, sites or elements are juxtaposed. Fifthly, 'temporal' heterotopias are connected with both the accumulation of time (exemplified in the museum) and its fleetingness (as evident in sites where time is transitory and precarious such as the fairground or festival). Lastly, 'heterotopias of ritual or purification' require a system of opening and closing which isolates them from other spaces whilst retaining their penetrability. Heterotopias are therefore ambivalent and uncertain spaces owing to the multiplicity of social meanings that are attached to them (Hetherington 1997:41).

Foucault ([1967] 1986:5) categorises these heterotopias according to spaces of crisis and deviance. Sites of crisis include shelters, such as orphanages, military camps, rest or retirement homes, as well as sacred, privileged or forbidden sites such as monasteries or brothels. Sites of deviance are those in which people whose behaviour is deviant in relation to the norm are placed, such as prisons, military camps, or psychiatric asylums. For Foucault, heterotopic sites can be heterogeneous collections of unified materials, social practices and/or events. Order is not established through resemblance (Hetherington 1997:43) but through a process of similitude, wherein meaning is dislocated through a series of deferrals established between a signifier and a signified (Hetherington 1997:43). Critically, they can be both:

marginal and central, associated with transgressive outsiderness as well as 'carceral' sites of social control and the desire for a perfect order. In both cases, heterotopia [sic] are sites of all things displaced, marginal, novel or rejected or ambivalent. (Hetherington 1997:46, 49, emphasis added)

In the sections to follow, we consider Bertha Marks's life experiences, as represented in the diary entries of Futility, as well as her diary itself as it features in the artwork, as heterotopic sites of crisis: 'spaces of alternate ordering', in which ambivalences of acceptance and complicity are juxtaposed with resistance and transgression.

\section{Heterotopias of displacement and alienation}

Bertha Marks's heterotopic experiences of dislocation, alienation and isolation from, and ambivalence to, her new environment are to some extent echoed in diary entries, letters and novels by many settler wives. Susan Bailey (1983:73) notes that whether they left England in 1690 or 1830, bound for North America, Australia, Canada, South Africa, New Zealand or elsewhere, these women must have faced emigration with trepidation. The disruption of ties with family and friends was difficult and breaking networks of female friendships that formed a support base, with little prospect of forming new ones, might have caused great sadness. Bailey (1983:73) cites Lillian Schlissel (1978), who, in writing about women settlers in the American west, concludes: 'migration was a major dislocation in the emotional fabric of women's lives'. 
As Van Heyningen (1993:23) comments, isolation was not just a physical state that gave women the leisure and desire to record their experiences - it also contributed to the making of those experiences and provided a space wherein subconscious tensions and fears could be articulated. Bertha Marks's sense of displacement and alienation following her relocation in South Africa is articulated by Mendelsohn (1991) as follows:

The inevitable culture shock for a young girl from a great industrial city and a protected, middle-class, Anglo-Jewish environment arriving at a remote farm in an alien countryside can only be imagined. Her reactions, unfortunately, are not recorded. (p. 34)

Bertha Marks's sense of displacement resulting from her new environment was physical, social, cultural and psychological. Like the seedling roses she imported weekly from Kent to plant in her Victorian English rose garden on the South African veld (Mendelsohn 1991:188) and like the medical reference to the heterotopia as a bodily site onto which 'alien' elements have been transplanted, she herself was grafted onto African soil. Such dislocation and relocation could be said to create a state of heterotopic crisis in which spatial, cultural and social relations are set in relations differing from each other. In order to articulate this state, in diary entry six of Futility, the artist extrapolated on Mendelsohn's (1991:34) words, attempting to identify with Bertha Marks's experience of dislocation through empathetic unsettlement:

I remember coming here in March 1885. How strange it was leaving Sheffield and my family to come to a remote farm in this alien country. There was nothing here but an old farmhouse; we had to ship all our furniture and household goods from England including my brass French bedstead with its patent woven wire mattress and feather bolster ... the agents also had to dispatch my threadle operated sewing machine together with a liberal supply of needles, as these could not be obtained in Pretoria. I still have to put in weekly orders for groceries and household necessities from Durban, including tins of salmon, sardines and lobsters, cotton reels and Pears soap. (Farber 2010: Component one, diary entry six)

Mendelsohn (1991:187) notes that despite the luxurious comforts of her surroundings, Zwartkoppies remained a place of emotional, intellectual and physical restriction and isolation for Bertha Marks; a 'gilded cage' where 'her husband left her "so much alone"'. To counteract her loneliness, she frequently travelled 'home' to England and extended her annual holidays at the coast, either in Durban or at the family holiday home, Hatherly Hall, in Muizenburg, Cape Town (Mendelsohn 1991:187). In diary entry four, I used factual information gained from the two primary sources in conjunction with imaginative projection to translate her experience of living in a space that was simultaneously luxurious and isolated; comfortable, yet physically and psychologically restricting:

For all the crowds that come every Sunday and the servants around me, I am so much alone at Zwartkoppies. Sammy is away on business most of the time, it takes two hours to do the 12-mile carriage drive to Pretoria, so trips to town cannot be undertaken everyday ... There are seldom visitors during the week ... it is so awfully quiet here! I long to have a conversation with just anyone, even one of the servants, but that would not be right and proper! I cannot wait for another trip home ... it is so hard to bring myself to come back here after being with people of my own kind. (Farber 2010: Component one, diary entry four)

Bertha Marks's experiences thus constitute a heterotopia of crisis that contains the unsettling juxtaposition of several paradoxical, ambivalent and incompatible spaces or sites in a single place. There is the juxtaposition of the real social space of her life in South Africa with the ideal, utopian vision of England as 'home'. This ambivalence is borne out in her desire to model her world in South Africa directly on her home country: for instance, she attempts to recreate 'England in Africa' by shipping furniture from Sheffield to Zwartkoppies and establishing an exact replica of a Victorian English rose garden at the entrance to the house. ${ }^{8}$ Although the luxurious mansion of Zwartkoppies could be considered as a utopia, it is a dystopia for Bertha Marks; a place of confinement, entrapment, isolation, for despite the vastness of the surrounding veld, she feels hemmed in, like a caged bird. Despite her husband's generous hospitality once a week, and although she is constantly surrounded by servants, she feels isolated and lonely. Yet, her loneliness and isolation are, in part, caused by her adherence to the politics of exclusion that underpinned colonial society, which prescribed the avoidance of others of different race, ethnicity, class, language and religion. ${ }^{9}$

\section{Heterotopias of acceptance, resentment and resistance}

Bertha Marks's sense of physical isolation was coupled with the intellectual, emotional, creative and psychological constraints of the patriarchal social constructs which dictated her life as a Jewish Victorian wife, ${ }^{10}$ mother and woman. Like their male counterparts, fin-de-siècle Jewish women in South Africa were expected to adopt a respectable, upper-middle-class identity; one that was White, urban and English-speaking (Krut 1985:183). Upper- and middle-class Victorian culture was governed by respectability: a code of conduct which was organised around a complex set of practices and representations which defined appropriate and

8.This desire to reproduce characteristic features of Britain in the colonies is characteristic of British immigrants. John Plotz (2007:660-661) explains that the Victorians were preoccupied with ways in which portable property, objects and victorians were preoccupied with ways in which portable property, objects and cultural practices could function as repositories of memory. Cultural portability of objects and practices from Britain to the colonies was a way of constructing self, community and nation, and establishing a sense of national culture and identity, in an otherwise unfamiliar, often alienating, environment. These 'containers' of memory strengthened the colonialist's bond to their former 'home', whils simultaneously reminding them of their distance from it. A resonant culturally portable object or practice could allow for the imaginative reconstruction of an entire absent realm; a 'home' away from home (Plotz 2007:661).

9.Furthermore, Bertha Marks's positioning of herself as a Jewish outsider (and therefore 'other') within the context of the White community in Pretoria sets her apart from those surrounding her. It may be argued that the loneliness and isolation which she experienced was exacerbated by her Jewishness, which set her culturally apart from neighbouring communities.

10.Mendelsohn (1991:197) notes that Bertha Marks's orthodoxy was an acculturated, secular one of the 'lukewarm, anglicised variety so characteristic of the Jewish elite in Victorian England'. Jewish dietary laws were loosely observed in her kitchen (Mendelsohn 1991:198) and, like many of her Anglo-Jewish contemporaries, Bertha Marks celebrated Christmas by hosting large annual Christmas parties at Zwartkoppies. However, the Marks family did celebrate the Jewish High Festivals Zwartkoppies. However, the Marks family did celebrate the Jewish High Festivals
and Passover. These, together with the rites of passage (such as male circumcision and bar-mitzvahs) were the most enduring of their Jewish observances. 
acceptable modes of behaviour, language and appearance (Lemmer 2007:28). These social rules and moral codes worked to regulate both gender and class identities (Davidoff \& Hall 2002:398; Nead 1988:28). Morality, a key component of respectability, was an essential to the civilising of an imperfectly organised and newly urbanised society (Seaman, in Lemmer 2007:28). Definitions of masculinity and femininity were key constructions within the moral order. Victorian culture was structured around a hierarchised ordering of gender, which placed women economically, socially, sexually and creatively in the lesser position (Malan 1996:12). In its underpinning paradigm of separate spheres, which provided a rigid framework that demarcated men's (public, exterior) and women's (private, interior) spaces, women were inextricably associated with domesticity and the home (Lemmer 2007:48), whereas the husband was considered as the authority within the marriage. The home was represented as a site of order; a 'haven' from the outside world (Mills 2005:128), of which the wife was the religious and moral centre (Mills 2005:58). Deemed the 'Angel of the House' (Mills 2005:58), she presided over the home and assuaged the man who was 'sullied' by contact with the outside world.

Ideally modest, passive, patient and unassuming, she was bound by the codes of sexual respectability and a sense of duty to her husband, family and home (Lemmer 2007:32). The 'true woman' was expected to honour, obey and occasionally amuse her husband, act as mistress of his household, rear his children and entertain his friends (Malan 1996:12). As Lynda Nead (1988:28) observes, 'the notion of respectability was defined for women in terms of dependency, delicacy and fragility; independence was unnatural, it signified boldness and sexual deviancy'. She continues that 'the notion of dependency was believed to be a natural and gratifying component of respectable femininity' (Nead 1988:29), in keeping with Victorian conceptions of sexuality that were founded on theories of natural or biological difference.

Given her position and gender, Bertha Marks was expected to adhere to the powerful constraints imposed upon her by these Victorian ideals of femininity (Mendelsohn 1991:183). ${ }^{11}$ As Mendelsohn (1991:181) observes, although Sammy and Bertha Marks's marriage was solid and enduring, 'it was very much a marriage of its time. Sammy Marks was a Victorian paterfamilias, continually chiding, instructing and exhorting his wife'. For Sammy Marks, his wife clearly belonged to a weaker sex, prone to idle chatter and preoccupied with trivialities (Mendelsohn 1991:182). He often assumed the position of authority, not only in his patriarchal role as head of the household, but also because he was 20 years her senior. For instance, when Bertha Marks fired a nurse she had hired against his wishes, he retorted:

11.As explained in diary entry three of Futility (Figure 3 ), upon their move to Parktown, Johannesburg in 1909, Bertha Marks was able to interact with women of her own class and background. The move offered her the opportunity to of her own class and background. The move offered her the opportunity to exercise her organisational abilities in a broader context than that of the domestic. This coincided with a new age associated with the emergence of what Riva Krut 1985:224) calls 'domestic feminists' - women who did not share the views of the militant feminists and suffragettes of their time, but who practised a tacit, cautious form of feminism. This form of feminism still foregrounded domesticity and the household, but allowed for a 'lady' to enter public life, albeit on a limited, feminine and non-profit basis.
I should like you to bear in mind and mark carefully for the future that when I tell you anything especially as to people's character's, you will allow me to be a better judge than you are, and it is only natural I should be so when you will consider the difference in years there is between us. (S. Marks 1902a)

Like many of his peers, Sammy Marks felt that his wife spent too lavishly, often chiding her in this regard. For instance, his reaction to her spending whilst on holiday in Europe in 1902 was:

It is no doubt needless for me to point out to you that you have spent a lot of money ... Do you expect to open a retail shop at Zwartkoppies, or are you afraid that the manufacturers will cease making more things? (S. Marks 1902c)

In keeping with Victorian ideals of femininity and separate spheres, he believed that a woman's proper place was the home and that her responsibilities lay in organising and directing the household (Mendelsohn 1991:182-183). Whilst she was holidaying in Taormina in 1906, he rebuked her for staying away from home too long:

I do not need to remind you that you have gone to Europe to recover your health ... When you have done this I would like you to come back here and take some of the responsibilities of the house off my shoulders. I have no time to look after such things, as I have more than enough to do with the business. (S. Marks, in Mendelsohn 1991:185)

In the diary entries comprising Futility, many of Bertha Marks's possible and actual frustrations around her husband's condescending, paternalistic and chauvinistic attitudes towards her are articulated. From the series of 10 prints of which Futility is comprised, the artist selected a quotation from diary extract eight, which, for her, seemed to epitomise these frustrations. This quotation forms the content of the third component of the work and is also the prompt for its title (Figure 8):

I went to the trouble of writing him a 24-page letter and do you know what his response was? 'There are certainly some amusing little things in it, but of course being a woman you must be excused!!' I often wonder if he really reads my letters? Perhaps I need only write short ones in the future. (Farber 2010: Component three; S. Marks 1902b; see also Mendelsohn 1991:182)

Sammy Marks airily dismissed the 'amusing little things' in a subsequent letter as 'what you would call women's talk' (S. Marks 1902b). In this extract, Bertha Marks's words seem particularly poignant. They speak of time, energy and effort wasted; of frustration and hurt at not being appreciated, acknowledged or heard by her husband, and of being dismissed and infantilised because she was a woman. Her words evoke what might be read as a deep sense of longing and unfulfilled desire, pointing to what she may have perceived as the futility of investment in her marriage.

As Sammy Marks was frequently away and because of the demands of his various businesses, Bertha Marks had to make many of the decisions about the children (Mendelsohn 1991:183). This, in addition to her aversion to her husband's large lunches which he held at Zwartkoppies every Sunday for business partners and politicians - 'I myself am sick of those Sunday Parties, as few of them were of any interest to me but 
it meant work worry and plenty of extra money to Pay at the end of the month' (Bertha Marks, in Mendelsohn 1991:185) ${ }^{12}$ - led her to admonish her husband for his insistence on putting business above family life and his continual attempts to exercise control over her. Her admonitions are cited in diary entry 10 as follows:

It is a great pity that there is really nothing that you do take pleasure in besides business. After all, one has one life only, it is quite right to work hard, but at the same time there is not a man who does not sometimes enjoy a little mild recreation ... I have just sent you a note saying that as you object to my taking a little mild recreation, I give up so much that other women of my age enjoy. You are too hard ... there is really no reason why I cannot go to a theatre now and again or to look on at a dance ... I am most careful of myself, the weather here is so mild, and I would never go out unless I felt quite fine. (B. Marks 1907)

In contrast to most Victorian women's diaries and letters that seldom mention marital conflict or dissatisfaction with life (Van Heyningen 1993:17), the above quotation reveals that, for Bertha Marks, letters to her husband were a means of voicing thoughts which, in a Victorian context, would have been considered 'inappropriate' to, and even transgressive of, her female nature; for her, the letter was occasionally used as a space in which 'unfeminine' emotions such as resentment, and resistance, could be expressed. For example, she fumed with exasperation at her husband's attitude towards her allegedly extravagant spending whilst she was on a trip to England. This unusually volatile outpouring of pentup anger and frustration showed her intense but impotent resentment of her total dependence on her husband:

I regret very much that you ... will not reply to my question re Money. How am I to pay my way and who is to pay all the bills ... It is absurd that you ignore the subject as to whom shall I look to for it if not to you. Have you any idea what a hundred and one little expenses crop up during a month besides bare living and hotel bills ... Believe me I can prove that none of the money that you gave me when we came home last March has been spent on myself up until now. If you only knew how tired and worried I am over such unsatisfactory affairs, you would be more reasonable and see matters in a proper way and as most husbands do to their wives ... I have no idea where to get my next shilling if it does not come from you and I think if you will only reason the matter out you will agree with me that I am placed in a very unpleasant and unsatisfactory position. (B. Marks 1906)

Such an expression of anger and resentment transgresses the Victorian codes of respectability and conduct, particularly those that inscribe the ideal of the self-sacrificing wife who obeys and submits to her husband. In this sense, her life experiences and diary are heterotopic sites in which conflicting positions of acceptance are juxtaposed with 'disobedient' assertions of a desire for independence. In their combination and juxtaposition of such conflicting positions in a single site, these heterotopic sites challenge established norms of thinking and the ways in which such thinking is ordered, becoming, to use Kevin Hetherington's (1997:7) words, 'spaces of an alternate ordering'. Hetherington (1997:36, 46; see also Topinka 2010:56) argues that because heterotopic sites can rupture and destabilise established orders, they have the potential to facilitate acts of resistance and transgression and, by the same token, processes of transgression and resistance can result in alternative forms of ordering. Thus, the heterotopias of Bertha Marks's life experiences and diary problematise the Victorian codes of respectability by revealing and destabilising the foundations upon which they were built.

\section{Heterotopias of complicity}

Whilst the above quotation indicates that even though she was a victim of the patriarchal ideologies underpinning colonial conceptions of femininity, as a colonial woman, Bertha Marks was also complicit in maintaining the racial, social and cultural prejudices and forms of subjugation that accompanied them.

Anne McClintock (1995:6) observes that although barred from formal power, colonial women experienced both the privileges and social contradictions of imperialism. These women served discreetly as colonial officer's wives and, like Bertha Marks, upheld the boundaries of empire and bore its children. Yet, as McClintock (1995) states:

marital laws, property laws, land laws and the intractable violence of male decree bound them in gendered patterns of disadvantage and frustration. The vast, fissured architecture of imperialism was gendered throughout by the fact that it was white men who made and enforced laws and policies in their own interests. Nonetheless, the rationed privileges of race all too often put white women in positions of decided - if borrowed power, not only over colonized women but also over colonized men. As such, white women were not the hapless onlookers of empire but were ambiguously complicit both as colonisers and colonized, privileged and restricted, acted upon and acting. (p. 6, emphasis added)

Janice Brownfoot (1984:189-190) outlines certain ways in which colonial women were complicit in upholding imperial power. She explains that the Victorians believed that White women brought with them to colonial territories 'civilising influences' thought to be beneficial to White men, the European communities and the British Empire. The community's places of dwelling and recreation were markers of European civilisation in a foreign world, often characterised by heat, luxuriant or dry vegetation, strange diseases and 'heathen customs'. Wives and family were seen to bring 'normality' to these sites, giving their menfolk a sense of stability and purpose (Brownfoot 1984:189). The significance of these 'civilising influences' was intricately bound to the assumption and maintenance of White supremacy. Western civilisation and standards had to be defended; the community had to maintain its Whiteness and remain united. By producing purebred children, recreating metropolitan domestic and social life and enforcing a social distance between subjects and their colonial rulers, wives were considered intrinsic to this maintenance and defence, and thus to the greater project of Empire-building. They foregrounded a European sense of a common Caucasianism, whilst also establishing more decorous, orderly and conformist communities than those of pioneering conditions 
(Brownfoot 1984:189-190). Wives were seen to stabilise both the community and its standards and, in so doing, helped to prevent White men from going troppo [mental] or 'native' or becoming alcoholics - behaviour which, as Brownfoot (1984:190) notes, compromised White prestige.

Therefore, as Mills (2005:127) observes, women's work within the domestic sphere did not simply support their husbands and community, but also produced 'a particular kind of colonial space', for, as Hilary Callan (1984:9) says, 'a properly managed home is more than a precondition of a civilizing mission: it is part of it'. In their role as 'Angel of the House', wives were afforded moral prestige, if not public power, and they were able to wield considerable influence within the domestic sphere (Giles 2004:12). Domestic rituals and conventions governing personal relations were often shaped by women's moral influence - a factor which tended to undermine the power of traditional patriarchy in the home. McClintock (1995:35) argues that this production of a 'British' domestic space within the colonies was considered an exemplar of correct and civilised living. The production of domesticity and class roles into domesticity was therefore central to imperialism: 'imperialism suffused the Victorian cult of domesticity and the historic separation of the private and the public, which took shape around colonialism and the idea of race' (McClintock 1995:36).

Bertha Marks occupied an ambivalent space in the relations of imperial power. She accepted and upheld colonial prejudices and discriminatory behaviours, perhaps not so much for the sake of acceptance and integration, but because these were ingrained conventions and norms of the colonial society of which she was an integral part. These prejudices are evident in the quotations reproduced as diary entry one (Figure 3), in which she displays her attitudes towards her black servants:

What I want is a good English parlour maid, one who has been in the Country for some years; also one who has no objection to coloured people, as I have two slightly coloured servants and one coloured boy. Should she object to occupying the same room as the Coloured Girls, I shall provide separate sleeping accommodation for her. (B. Marks 1895)

From these words, one may deduce that Bertha Marks associated the Victorian code of respectability and its attendant morality with White maids, specifically those from Britain. In her first sentence, she clearly differentiates the White, English servant whom she saw as a 'parlour maid' from Black female servants, whom she refers to as 'girls'. Furthermore, she also acknowledges spatial separations according to race and class, as the White English parlour maid was not necessarily expected to sleep in the same space as the 'Coloured Girls'.

These conventions of distance and separation led to what McClintock $(1995: 33,47)$ describes as the middle-class's 'intense preoccupation with rigid boundaries'. Paranoia around the nineteenth-century conception of hybridity as miscegenation led to vigilant measures being taken against illicit domestic relations, concubinage and racial interrelations in the colonies at the turn of the century, given that the latter represented paramount danger to racial purity and cultural identity. These fears of 'degeneration' and miscegenation threatened the core Victorian values of middle-class morality and motherhood. To counteract this threat, European women created and protected colonial prestige by insulating their men from cultural and sexual contact with colonised women (Stoler 1989:649).

Anxieties around the desecration of sexual boundaries and its consequences were accompanied by panic around blood contiguity (communication of disease though touch; contamination). The latter took on metaphoric dimensions as biological images of disease, pestilence and contagion were associated with wealthy Victorians' anxieties about the lower classes who were considered to be mentally, morally and physically 'degenerate'; carriers of 'bad blood' (McClintock 1995:46). McClintock (1995:47) describes how 'the poetics of contagion' was used as justification for a politics of exclusion and gave social sanction to the middle-class fixation with boundary sanitation. As McClintock (1995:47) summarises, these 'sanitation syndromes were in part genuine attempts to combat the "diseases of poverty"', but also served 'to rationalize and ritualize the policing of boundaries between the Victorian ruling elite and the "contagious classes"' in both the imperial metropoles and in the colonies.

This policing of boundaries would have been maintained within the domestic sphere, given that this represented a site where class difference could, potentially, come into contact. In the Victorian household, distinctions between servants and family were demarcated through its spatial organisation $^{13}$ and the social rituals that kept employer and employee at a distance from each other (see Giles 2004:67). It was the mistress of the household's duty to impose middleclass notions of order and discipline, not only on herself and her children, but also on her staff. Callan (1984:8) observes that because women were primarily responsible for the maintenance of class distinctions within the home, they had to practice what she calls a 'suppression of perception' in order to create and maintain social distance between themselves and the African people who surrounded them on a daily basis. Suppression of perception entailed a form of dehumanisation, or 'not seeing' the servants' presence despite awareness that it exists. According to Simon Dagut (2000), suppressed perception was used as:

a psychological mechanism for the construction, maintenance and reinforcement of social distance. In turn, the construction of social distance, partial and contested though it was, played an important part in making the oppressive features of colonialism seem socially and psychologically possible - or even admirable to the colonisers. (p. 561)

To some extent, these dehumanisations, as well as an awareness of class and racial boundaries, are borne out in Futility. For example, whilst on a hiring campaign for servants in England, Bertha Marks comments that they could not do with less than:

13.Families occupied the same overall space of their houses and gardens with their servants, but there were separate 'islands' within that space. They interacted only in the sphere of housework and service (Kirkwood 1984:157). 
A Cook and Kitchenmaid a butler and someone to help him, 2 Housemaids and 1 Housemaid and not counting the necessary Kaffirs to do all the children's quarters and wait upon them at meals etc. Then the Laundry requires people and Mostert is not certainly to see to the dairy and my Poultry as it will be required on my return ... Then a Gove[erness] for Doll a nurse for Phil and a maid for myself. I have had enough inconvenience not having one with me all this time. Re a Butler you had better see if you can get one there ... or I shall have to bring one out. (B. Marks 1906)

We propose that the perception of servants as 'dehumanised labour' reflected in this quotation may be seen as an instance of suppressed perception. Adherence to Victorian codes of respectability meant that it would not be 'right and proper' for her to engage in conversations with servants that did not pertain to the employer-employee or domestic mistressservant spheres. Whilst fairly standard and typical within a colonial context, it is nevertheless ironic that her perceived 'superiority' as a White colonial woman defined her relations with her servants, despite any anti-Semitism she may have had to contend with in England ${ }^{14}$ and South Africa, and despite her subjugated position within patriarchal Victorian hierarchies. The ironies of upholding and fostering the colonial position of presumed innate White superiority seems to have been lost on Bertha Marks, as they were to many of her generation, position and class.

\section{Conclusion}

The philosophical ideals of progressionalism and rationalism which characterised the Victorian era form a backdrop to its deeply rooted racial and gender constructions. The utopian ideals inherent in Victorian society (Dreyer 2010:4) run according to its codes of respectability were underpinned by the concept of the teleological 'good ending'. The hierarchic ordering of gender relationships and their attendant codes of conduct, as well as conception of the home as a site of order (Mills 2005:128), were viewed as intrinsically 'good' and hypothetically necessary to ensure a utopic, 'optimum society' (Manuel, in Dreyer 2010:4). Eurocentrism, patriarchy and White supremacy are therefore aligned with a utopian ideal of destiny (predetermined by biologically gendered differences) and existential happiness.

Bertha Marks's life experiences and diaries thus present heterotopias of crisis which, whilst reflecting its structure, also undermine this conception of the ordered, stable, 'perfect society'. Within these heterotopias, the gap between the utopian space of the ideal Victorian society and real space of her social and physical environment, which she experienced a place of restriction, subordination, limitation and suppression, is an ambivalent site of dislocated otherness. In the context of Bertha Marks's position as an immigrant in the social world of colonial South Africa, and given her role as Victorian wife and mistress of the household, her life experiences and dairy reflect her conflicting attitudes of acceptance, resentment, resistance complicity; whilst maintaining the racial and social of Jews did have some negatively charged dimensions, but were, on the whole, relatively benign. prejudices of the colonial era from within the conventions assigned to her gender, she was simultaneously constrained by, and resistant to, its dictates. Through the combination and juxtaposition of such conflicting positions in a single site, the heterotopias of Bertha Marks's life experiences and diary become 'spaces of alternate ordering': by reflecting aspects of European supremacy and its concrete links to domesticity and nationhood, these heterotopias of crisis expose the doublestandards, hypocrisy and chaos underlying colonial and Victorian ideologies by revealing their cultural arrogance and racial divides. In rupturing and destabilising the foundations upon which Victorian codes of respectability were built, these heterotopias can be seen to facilitate acts of resistance and transgression.

\section{Acknowledgements Competing interests}

The authors declare that they have no financial or personal relationships which may have inappropriately influenced them in writing this article.

\section{Authors' contributions}

L.F. (University of Johannesburg) is the primary author, from whose art exhibition and doctoral dissertation this article is drawn. E.D. (University of Pretoria) was the primary author's doctoral supervisor on said dissertation.

\section{References}

Bailey, S., 1983, Women and the British Empire: An annotated guide to sources, Garland, New York.

Bradford, H., 1996, 'Women, gender and colonialism: Rethinking the history of the British Cape colony and its frontier zones c. 1806-1870', The Journal of African History 37(3), 351-370.

Brownfoot, J.N., 1984, 'Memsahibs in colonial Malaya: A study of European wives in a British colony and protectorate 1900-1940', in H. Callan \& S. Arderner (eds.), The incorporated wife, pp. 186-210, Croom Helm, London.

Callan, H., 1984, 'Introduction', in H. Callan \& S. Arderner (eds.), The incorporated wife, pp. 2-26, Croom Helm, London.

Callan, H. \& Arderner, S. (eds.), 1984, The incorporated wife, Croom Helm, London.

Dagut, S., 2000, 'Gender, colonial women's history and the construction of social distance: Middle-class British women in later nineteenth-century South Africa', Journal of Southern African Studies 26(3), September, 554-572.

Davidoff, L. \& Hall, C., 2002, Family fortunes: Men and women of the English middle class 1780-1850, 2nd edn., Routledge, London.

Dreyer, E., 2010, 'Referee's report on presentation of visual research: Leora Farber. Dept. Visual Art, Faculty of Art, Design and Architecture, University of Johannesburg, Johannesburg. (Unpublished)

Erlank, N., 1995, 'Thinking it wrong to remain unemployed in pressing times: The experiences of two English settler wives', South African Historical Journal 33(November), 62-82.

Erlank, N., 1996, 'Writing women in(to) early nineteenth century Cape Town', Kronos 23(November), 75-90.

Farber, L., 2007-2008, Dis-Location/Re-Location exhibition, installed at The Albany History Museum, Grahamstown 28 June - 27 July 2007; The Nelson Mandela Metropolitan Art Museum, Port Elizabeth 07 August - 09 September 2007; The South African Jewish Museum, Cape Town, 30 September - 15 November 2007; The US Art Gallery, Stellenbosch 16 October - 17 November 2007; The Oliewenhuis Art Museum, Bloemfontein 04 December 2007 - 27 January 2008; The Johannesburg Art Gallery 10 February-13 April 2008; The Durban Art Gallery 15 May - 27 July 2008.

Farber, L., 2010, The Futility of Writing 24-Page Letters artwork, Faculty of Art, Design and Architecture gallery, University of Johannesburg, 12-23 July.

Foucault, M., [1967] 1986, 'Of other spaces', transl. J. Miskowiec, Diacritics 16(1), Spring, 22-27.

Giles, J., 2004, The parlour and the suburb: Domestic identities, class, femininity and modernity, Berg, Oxford.

Hetherington, K., 1997, The badlands of modernity: heterotopias and social ordering, Routledge, London. 
Hugo, M., 1989, 'Die dagboek as historiese bron - met verwysing na die dagboek van H.C. Bredell [The diary as historical source - with refernce to the diary of H.C. van H.C. Bredell [The diary as historic
Bredell]', Historia 34(2), 108-118.

Johnson, P., 2006, Unravelling Foucault's different spaces, History of the Human Sciences 19(4), 75-90, viewed 22 April 2011, from http://hhs.sagepub.com/ content/19/4/75

Jorgensen, C.E., 2010, 'Irrigating the garden: Cultivating relations between nature, artifice, indigenous and alien within the South African context', MFA dissertation, Michaelis School of Fine Art, University of Cape Town.

Kirkwood, D., 1984, 'Settler wives in Southern Rhodesia: A case study', in H. Callan \& S. Arderner (eds.), The incorporated wife, pp. 113-163, Croom Helm, London.

Krut, R.M., 1985, 'Building a home and a community: Jews in Johannesburg, 18861914', DPhil dissertation, School of Oriental and African Studies, University of London.

LaCapra, D., 2001, Writing history, writing trauma, Johns Hopkins University Press, Baltimore.

Lemmer, C., 2007, 'Victorian respectability: The gendering of domestic space', MIA dissertation, The built environment and information technology, Faculty of Engineering, University of Pretoria.

Malan, A., 1996, 'The use of historical photographs as source for cultural history: The Sammy Marks photograph collection', MA, Faculty of Arts, University of Pretoria.

Marks, B., 1895, 'Letter to Klegg', Samuel Marks Papers, University of Cape Town Libraries, SM/B2/11: B. Marks-Klegg, 20 May 1895.

Marks, B., 1906, 'Letter to Samuel Marks', Samuel Marks Papers, University of Cape Town Libraries, SM/B5: B. Marks-Marks, 29 April 1906.

Marks, B., 1907, 'Letter to Samuel Marks', Samuel Marks Papers, University of Cape Town Libraries, SM/B2/19: B. Marks-Marks, 08 July 1907.

Marks, S., 1902a, 'Letter to Bertha Marks', Samuel Marks Papers, University of Cape Town Libraries, SM/B2/18: Marks-B. Marks, 24 July 1902.

Marks, S., 1902b, 'Letter to Bertha Marks', Samuel Marks Papers, University of Cape Town Libraries, SM/B2/18: Marks-B. Marks, 16 August 1902.

Marks, S., 1902c, 'Letter to Bertha Marks', Samuel Marks Papers, University of Cape Town Libraries, SM/B2/19: Marks-B. Marks, 04 October 1902.
McClintock, A., 1995, Imperial leather. Race, gender and sexuality in the colonial contest, Routledge, New York.

Mendelsohn, R., 1991, Sammy Marks: The uncrowned king of the Transvaal, David Philip, Cape Town.

Mendelsohn, R., 2008, 'The gilded cage: Bertha Marks at Zwartkoppies', in B. LawViljoen (ed.), Dis-Location/Re-Location: Exploring alienation and identity in South Africa, pp. 27-39, David Krut Publishing, Johannesburg.

Mendelsohn, R. \& Shain, M., 2008, The Jews in South Africa: An illustrated history, Jonathan Ball, Johannesburg.

Mills, S., 2005, Gender and colonial space, Manchester University Press, Manchester.

More, T., [1516] 1985, Utopia, Dent, London.

Nead, L., 1988, Myths of sexuality: Representations of women in Victorian Britain, Basil Blackwell, Oxford.

Plotz, J., 2007, 'The first strawberries in India: Cultural portability in Victorian Greater Britain', Victorian Studies 49(4), Summer, 659-684.

Rosner, V., 1999, 'Doris Lessing, colonial architecture, and the reproduction of mothering', Tulsa Studies in Women's Literature 18(1), Spring, 59-89.

Schlissel, L., 1978, 'Mothers and daughters on the western frontier', Frontiers III(2), Summer, 29-33.

Shain, M., 1994, The roots of antisemitism in South Africa, Witwatersrand University Press, Johannesburg.

South African History Online, n.d., Towards a people's history. First Anglo-Boer war 1880-1881, viewed 28 May 2012, from http://www.sahistory.org.za/southafrica-1806-1899/first-anglo-boer-war-1880-1881

Stoler, A., 1989, 'Making empire respectable: The politics of race and sexual morality in 20th-century colonial cultures', American Ethnologist 16(4), November, 634-660.

Topinka, R.J., 2010, 'Foucault, Borges, heterotopia: Producing knowledges in other spaces', Foucault Studies 9(September), 54-70.

Van Helten, J.J. \& Williams, K., 1983, 'The crying need of South Africa: The emigrationof single British women to the Transvaal, 1901-10', Journal of South African Studies 10(1), October, 17-38.

Van Heyningen, E., 1993, 'The diary as historical source', Historia 38(1), 14-25. 